\title{
Helicobacter pylori Status
}

National Cancer Institute

\section{Source}

National Cancer Institute. Helicobacter pylori Status. NCI Thesaurus. Code C157436.

The finding of whether an individual is infected with the H.pylori bacteria. 